\title{
Application of alkylresorcinols in an organic apple orchard for protection against storage diseases
}

\author{
I. Tahir ${ }^{1}$, E.S. Dey ${ }^{2}$ and H. Nybom ${ }^{3}$ \\ ${ }^{1}$ Department of Plant Breeding, Swedish University of Agricultural Sciences, Alnarp, Sweden \\ 2 Division of Pure and Applied Biochemistry, Lund University, Lund, Sweden \\ ${ }^{3}$ Department of Plant Breeding-Balsgård, Swedish University of Agricultural Sciences, Kristianstad, Sweden
}

\section{Summary}

Each year, fungal storage diseases destroy large amounts of apple, especially in organic orchards. In the present study, antifungal activity of a rye branbased remedy with 5-n-alkylresorcinols (ARs) was investigated. In 2014 and 2015, 'Amorosa' apple trees in an organic orchard were sprayed with a $0.025 \%$ AR emulsion pre-harvest, once or twice at different points in time. In addition, emulsions with different AR concentrations were applied postharvest on fruit inoculated with three different fungi (in vivo) and on fungal mycelium and conidia (in vitro). Fruits from trees sprayed in August and/or September had significantly less fungal decay in comparison with fruits from unsprayed trees, both at harvest and after storage in regular air and in controlled atmosphere condition (CA). Effects on fruit quality were small and inconsistent whereas yield was significantly reduced, especially after early-season applications (June, July). Yield was, however, similarly reduced when a reference emulsion without ARs was applied suggesting that this effect was not brought about by the ARs. The in vivo and in vitro experiments showed that anti-fungal activity increased with higher AR concentrations. Further experiments with late-season applications and higher AR concentrations should be undertaken.

\section{Keywords}

alkylresorcinols, fungal decay, Malus domestica, organic production, plant protection, storage decay

\section{Introduction}

Storage diseases caused by various fungal pathogens, decrease fruit quality and restrict the storage potential of apple around the world (Jing et al., 2014). Significant amounts of fruit harvested in organic orchards are spoiled by these pathogens each year (Jönsson, 2007; Tahir and Nybom, 2013). Pre- and post-harvest application of chemical fungicides is, however, decreasing also in conventional orchards due to the growing concern for human health impact and environmental protection. Consequently, replacement of chemical fungicides by biologically active natural compounds, has become an important challenge in horticultural research (Arif et al., 2009). Biological pesticides such as certain yeasts and bacteria have positive effects against storage diseases, either on their own (Nunes et al., 2007; Morales et al., 2010; Di Francesco et al., 2016) or in combination with plant hormones, i.e., indole-3-acetic acid (Yu et al., 2009) or chemicals such as sodium bicarbonate. However, the use of such organ-

\section{Significance of this study}

What is already known on this subject?

- Fungal diseases cause serious economic losses during fruit storage. Alkylresorcinols can decrease the symptoms on harvested fruit inoculated with fungal spores.

\section{What are the new findings?}

- Spraying with alkylresorcinols in the field protects the fruit significantly from several fungi that cause damage at harvest and after storage.

What is the expected impact on horticulture?

- Development of a commercial product with alkylresorcinols could be economically beneficial for growers of apple and other fruits and vegetables.

isms can have side effects and may also be pathogen-dependent (Boyd-Wilson et al., 2006). Essential oils and volatile compounds have shown inhibitory effects on fungal growth (Feliziani et al., 2013). Chitosan application, both pre- and postharvest, reduces the growth of decay-causing fungi and foodborne pathogens and induces resistance responses in host tissues (Romanazzi et al., 2017). Physiological stress, i.e., heat treatment, can act both as a surface disinfectant and for boosting endogenous defense mechanisms in the fruit (Sholberg et al., 2000; Saftner et al., 2003). However, heat treatment is not yet widely used since the effect varies widely due to temperature and exposure period (Tahir et al., 2009).

Various plant defense compounds such as antimicrobial phenols are being studied to an increasing extent (Dai and Mumper, 2010; Ahuja et al., 2012). Alkylresorcinols (ARs) and their derivatives constitute a group of non-isoprenoid lipids belonging to the phenols (Baerson et al., 2010). They are found in, e.g., the pericarp of cereals (Dai and Mumper, 2010) and in the peel and seeds of mango (Riberio et al., 2008). Wheat and rye contain the highest concentrations of ARs (Ross et al., 2004). ARs are synthesized as a response to stress factors during normal plant development (Stasiuk and Kozubek, 2010), and are involved in the regulation of host-pathogen relationships (Kozubek et al., 2001). They play an important role in plant defense such as in the resistance of barley seeds against Aspergillus niger and Penicillium chrysogenum (García et al., 1997) and of mango fruits against Alternaria alternata (Cojocaru et al., 1986).

In a previous study, application of AR emulsions reduced mycelial growth of Penicillium expansum and Neofabraea perennans as well as postharvest decay in apple fruits that had 
been inoculated with spores of the above mentioned pathogens (Tahir et al., 2014). The four apple cultivars ('Aroma', 'Ingrid Marie', 'Frida' and 'Gloster') used in that study are commonly grown in the Nordic countries, and exhibit variable levels of storage disease susceptibility.

The present study aimed to investigate whether preharvest application of an AR emulsion can reduce symptoms of spontaneously occurring storage diseases. In addition, solutions with different AR concentrations were applied in vitro and in vivo to assess potential antifungal activity.

\section{Materials and methods}

\section{Isolation of ARs}

Alkylresorcinols (ARs) were isolated from raw, industrial grade rye bran (Nord Mills, Malmö, Sweden). Bran was suspended in de-ionized water $(1: 10 \mathrm{w} / \mathrm{v})$ containing a protease and a thermostable alpha-amylase $(0.1 \% \mathrm{w} / \mathrm{v})$ with the trade names Alcalase ${ }^{\circledR} 2.4 \mathrm{~L}$ and Termamyl ${ }^{\circledR} 120$ L (Novozymes A/S, Bagsværd, Denmark), to remove proteins and starches. The suspension was mixed and kept at room temperature overnight. Solubilized and suspended material was removed by filtration until the filtrate was free from opaqueness. Excess water was removed from the remaining thick slurry using a kitchen juice centrifuge followed by drying in an aerated oven at $60^{\circ} \mathrm{C}$ (Labora, Stockholm, Sweden). The starting mass was reduced by $25-35 \%$, depending on the rye bran batch. The dried material was ground using a blender (Sandstrom, Hempstead, UK) producing a particle size of $0.5-1 \mathrm{~mm}$, and containing $9-10 \%$ water as evaluated after freeze-drying.

A two-step sc- $\mathrm{CO}_{2}\left(\mathrm{CO}_{2} \geq 99.998 \%\right.$, AGA Gas, Sweden $)$ extraction process and characterization of the extract was undertaken as previously described (Dey et al., 2009). Ten grams of material were loaded in a thimble $(100 \mathrm{~mL}$ of empty volume). The first extraction step was carried out at $70^{\circ} \mathrm{C}$ and 2 hours, and the co-solvent rate (ethanol) was 0.06 mass $\%$ of carbon dioxide flow rate. The second step was carried out at $45^{\circ} \mathrm{C}$ for 4 hours, with ethanol at 10 mass $\%$ of carbon dioxide flow rate. In both steps, flow rate of $\mathrm{CO}_{2}$ was $10 \mathrm{~g} \mathrm{~min}^{-1}$, and the $\mathrm{CO}_{2}$ pressure was kept at 250 bars. The resulting polar and amphiphilic material collected with ethanol was transferred to 50-mL Falcon tubes and placed in a desiccator kept in dark, then attached to a vacuum system to remove the ethanol. The extract was flashed with nitrogen and stored at $-20^{\circ} \mathrm{C}$ until used.

The AR concentration was quantified using the Fast Blue B colorimetric method (Gajda et al., 2008) with synthetic standards for the standard curve monitoring the optical changes on a spectrophotometer DU 800 (Beckman Coulter, Lab Vision, Sweden), followed by high pressure liquid chromatography (HPLC), and high performance thin layer chromatography (HPTLC) to evaluate the quality and to determine the amount of pure ARs.

For laboratory tests, four emulsions with different AR concentrations (reference: 0.0\%, AR1: 0.025\% (w/v), AR2: $0.1 \%$ and AR3: $0.2 \%$ ) were prepared, all containing $0.1 \%$ $(\mathrm{w} / \mathrm{v})$ xanthan gum, $0.5 \%(\mathrm{w} / \mathrm{v})$ Synperonic $91 / 6,0.2 \%$ $(\mathrm{w} / \mathrm{v})$ Tween $20,1 \%(\mathrm{w} / \mathrm{v})$ trioleate, $2 \%(\mathrm{w} / \mathrm{v})$ oleylalcohol, $2 \%\left(\mathrm{w} / \mathrm{v}\right.$ ) PEG 400 and $5 \%(\mathrm{w} / \mathrm{v}) \mathrm{CaCl}_{2}$. The solutions were homogenized with an Ultra Turrax, at 13,500 rpm for $5 \mathrm{~min}$ with 1-min breaks (Dey et al. 2013). AR1 was used also for the orchard tests, except that $\mathrm{CaCl}_{2}$ was deleted from the emulsion in 2015 because of its putative negative effect on plant leaves.

\section{Treatments in the orchard}

Pre-harvest AR applications were carried out in 2014 and 2015 in a commercial, organic orchard in Kivik (southeastern Sweden, 56 $6^{\prime} 23^{\prime \prime} \mathrm{N}$; 14 40 $40^{\prime} 57^{\prime \prime} \mathrm{E}$ ) with 'Amorosa' (red sport of 'Aroma') apple trees on rootstock M26, planted in 2011 at $1.25 \times 4 \mathrm{~m}$ (in total 2,000 trees ha-1). In 2014, 78 trees were chosen and divided into 13 treatment groups of 6 trees each. In 2015, 90 trees were chosen and divided into 15 groups of 6 trees each. One group was left untreated as a control both years while the other treatment groups were sprayed once or twice each season, with $0.5 \mathrm{~L}$ per tree of either AR1 or the reference emulsion, once in June, July (only in 2015), August or September or twice in June and August, June and September, or August and September.

In 2015, to prevent them from acting as a source of fungal infection, fruits dropping to the ground in June and July were removed, while fruits dropping in August or September were collected at the day of harvest. Fungi on these fruits were identified based on visible symptoms on fruit, mycelium shape and conidia shape.

Commercial harvesting date was determined as Streif index $=0.18$ (based on soluble solids concentration, firmness and starch conversion degree) (Streif, 1996). Fruit from each treatment were picked, counted, weighed and divided into three sets; one set ( 30 fruits) was used to evaluate fruit quality at harvest whereas the other sets (75 fruits each) were put either in cold storage $\left(2^{\circ} \mathrm{C}\right.$ and $\left.85 \% \mathrm{RH}\right)$ or in controlled atmosphere (CA, $2.0 \mathrm{kPa} \mathrm{O}_{2}$ and $2.0 \mathrm{kPa} \mathrm{CO}_{2}$ at $2^{\circ} \mathrm{C}$ ).

At harvest, fruit firmness, soluble solids content (SSC) and color was estimated on 30 fruits per treatment ( 5 fruits tree-1), using a penetrometer (Model FT 327; Effigi, Italy; plunger diameter of $11.1 \mathrm{~mm}$, depth of $7.9 \mathrm{~mm}$ ), a refractometer (Atago PR-100; Atago Co. Ltd., Tokyo, Japan) and a colorimeter (Minolta Ltd., Osaka, Japan). Firmness and SSC were expressed in $\mathrm{kg} \mathrm{cm}^{-2}$ and percentage, respectively. Skin color was expressed as color index $\mathrm{CI}\left(\mathrm{CI}=(1,000 \times \mathrm{a})\left(\mathrm{L}^{*} \mathrm{~b}\right)^{-1}\right.$, where $(+a)$ indicates red color, $(-a)$ green color, $(+b)$ yellow color, $(-\mathrm{b})$ blue color, and (L) is the luminosity from white to black.

Stored fruits were evaluated after five months in storage chambers and after one week in $20^{\circ} \mathrm{C}$ (shelf life). Natural fungal decay was determined as percentage damaged fruit, the pathogens causing decay were identified, and fruit quality was estimated (as above) on 15 fruits per treatment.

\section{Preparation of inoculums and fruit inoculation}

The pathogens P. expansum, N. perennans, Monilinia fructigena and Colletotrichum acutatum were isolated from naturally infected apples in 2015 with typical symptoms of blue mold, lenticel rot, brown rot and bitter rot, respectively. Fruit surface was sterilized for $30 \mathrm{~s}$ with $70 \%$ ethanol and rinsed with sterile distilled water. Small sections from the growing margin of the fruit rot lesion were plated on PDA at $22^{\circ} \mathrm{C}$ for the first and third pathogen, and on MEA at $20^{\circ} \mathrm{C}$ for the other two pathogens. The plates were maintained for less than two weeks. Then hyphal tips were transferred to new PDA and MEA plates, respectively, and incubated at the same temperatures for 2 weeks in order to obtain pure cultures. Thereafter, the pathogens were maintained separately as pure cultures at $4^{\circ} \mathrm{C}$. Conidial suspensions of the four pathogens were prepared by removing spores from the surface of the cultures on PDA and MEA, respectively, and suspending them in 5-mL sterile distilled water containing $0.05 \%(\mathrm{v} / \mathrm{v})$ Tween 80. The suspensions were filtered through four layers of sterile cheesecloth to remove any adhering mycelia, and 
spore concentrations were determined with a hemacytometer and adjusted to $1 \times 10^{5}$ conidia $\mathrm{mL}^{-1}$. These suspensions were used to test the antifungal effect of ARs in vivo and in vitro (Tahir et al., 2014).

In 2015, 'Amorosa' fruits were harvested from unsprayed trees in the same organic orchard (Streif index $=0.18$ ), washed with sterilized water, wounded twice on both sides to a depth of $3 \mathrm{~mm}$, and inoculated by pipetting $20 \mu \mathrm{L}$ of a conidial pathogen suspension into each of the wound sites. The material was divided into three groups; group 1: a set of 180 fruits was inoculated with P. expansum; group 2: a set of 180 fruits was inoculated with $M$. fructigena; group 3: a set of 180 fruits was inoculated with $N$. perennans. Each group was subsequently divided into 5 subgroups. Three hours after inoculation, four of these subgroups were sprayed with $10 \mathrm{~mL}$ of the reference emulsion (0.0\%), AR1 (0.025\%), AR2 (0.1\%), and AR3 $(0.2 \%)$ respectively, while the fifth subgroup was left without any treatment as a control. All groups were kept in cold storage $\left(2^{\circ} \mathrm{C}\right.$ and $\left.85 \% \mathrm{RH}\right)$ for 8 weeks. At the end of the storage period, decay on fruits inoculated with $P$. expansum and $M$. fructigena was evaluated directly while fruits inoculated with $N$. perennans were transferred to plastic boxes $\left(18 \pm 2^{\circ} \mathrm{C}\right.$ and $\left.80 \% \mathrm{RH}\right)$ for one week before evaluations. Decay severity was estimated as surface decay lesion diameter. The inhibition level was calculated as a percentage related to lesion diameter on inoculated but untreated fruit.

\section{In vitro antifungal activity of ARs}

The antifungal capacity of ARs was evaluated both as inhibition of mycelial growth and as inhibition of conidia viability according to Pérez-Alfonso et al. (2012). Mycelial plugs (10 $\mathrm{mm}$ in diameter) were transferred from 10-dayold pure cultures of $P$. expansum onto 75 plates containing PDA amended with streptomycin sulphate $\left(250 \mathrm{mg} \mathrm{L}^{-1}\right)$. After 3 hours, the plates were divided into five groups of 15 plates each; four of these groups were sprayed with $1 \mathrm{~mL}$ of the reference emulsion, AR1, AR2 or AR3, respectively, while the fifth group was left without any treatment as a control. Two other groups of 75 plates each, were treated similarly but with different fungi: C. acutatum and N. perennans, respectively. Mycelial growth of the three pathogens was determined as the increase in colony diameter after 10 days of incubation at $22^{\circ} \mathrm{C}$ for $P$. expansum and at $20^{\circ} \mathrm{C}$ for the other two pathogens. This experiment was performed three times in 2015.

Conidia were collected from 10-day-old pure colonies of P. expansum and transferred into $5 \mathrm{~mL}$ sterile distilled water containing $0.05 \%(\mathrm{v} / \mathrm{v})$ Tween 80 . The suspensions were filtered and its concentration was adjusted $\left(10^{5}\right.$ conidia $\left.\mathrm{mL}^{-1}\right)$ as described above. A $0.5 \mathrm{~mL}$ of this suspension was transferred to each of five Eppendorf tubes $(1.5 \mathrm{~mL})$, four of them containing $0.5 \mathrm{~mL}$ of AR1, AR2, AR3 and the reference emulsion respectively, while the fifth tube was left without any treatment as a control. This process was similarly repeated twice with different fungi: C. acutatum and $N$. perennans, respectively. The tubes of the three groups were incubated at $22^{\circ} \mathrm{C}$ for 24 hours. Then, $100 \mu \mathrm{L}$ of each tube was uniformly distributed onto three PDA plates amended with streptomycin sulphate (250 $\mathrm{mg} \mathrm{L}^{-1}$ ). Plates were incubated as above and the number of colony forming units (CFU) was recorded after 10 days. This experiment was performed three times in 2015.

\section{Statistical analysis}

A complete randomized design was adopted in this study. Data were treated with a GLM-analysis of variance with emulsions, spraying frequency and time and their interactions as fixed effects for yield, fruit weight, fruit quality at harvest and fruit storage potential (decay occurrence and quality decline) after storage. Multiple comparisons were made with Tukey's post hoc test $(\alpha=0.05)$. All statistics were performed by using Minitab 17.2.4.0 (Minitab Ltd., State College, PA, USA).

\section{Results}

\section{Effects of orchard treatments on yield and fruit weight}

Application of the AR emulsion decreased yield in 2014 (mean yield for all AR-treated trees: $6.1 \mathrm{~kg}$ ) in comparison with unsprayed trees $(7.5 \mathrm{~kg}$ ) as well as in 2015 (AR-treated trees $3.2 \mathrm{~kg}$, unsprayed trees $8.5 \mathrm{~kg}$ ). Application of the reference emulsion resulted in a slightly less severe decrease (mean yield $6.3 \mathrm{~kg}$ in 2014 and $4.3 \mathrm{~kg}$ in 2015). Results for the individual treatments were inconclusive but earlier treatments (June, July) with AR or reference emulsions had a more pronounced negative effect on yield compared to later treatments (August, September) (Table 1).

Due to abundant early fruit drop in 2014, mean weight of fruit harvested on the experimental trees reached $171 \mathrm{~g}$, whereas less fruit drop and smaller fruit (106 g) was encountered in 2015. For AR-treated trees mean fruit weight was $158 \mathrm{~g}$ and $104 \mathrm{~g}$ in 2014 and 2015, respectively, for reference solution-treated trees $174 \mathrm{~g}$ and $107 \mathrm{~g}$, and for unsprayed trees $112 \mathrm{~g}$ and $122 \mathrm{~g}$. Pearson correlation analysis for yield and fruit weight across all experimental trees indicated an almost significant, negative correlation in $2014(\mathrm{r}=-0,238$, $\mathrm{df}=77, P=0.054$ ) and a strong, positive correlation in 2015 $(\mathrm{r}=0.379, \mathrm{df}=89, P<0.001)$. Fruit weight varied considerably between treatments but there were no consistent effects related to spraying with the AR and reference emulsions.

\section{Effects of orchard treatments on fallen fruit}

All fruit collected from under the experimental trees just before harvesting in 2015 were affected by fungal decay, mostly Monilinia fructigena. Spraying the trees with the AR emulsion significantly decreased the quantity of infected fallen fruit compared to unsprayed trees but there were no consistent effects from spraying time or spraying frequency (Table 2). Spraying trees with the reference emulsion had a smaller but still significant effect, except when the spraying was undertaken in June. Calculated over all treatments, application of the AR emulsion lowered the amount of infected fallen fruit by $42 \%$ compared to application of the reference emulsion.

\section{Effects of orchard treatments on fruit quality at harvest}

Effects of spraying the trees with either the AR or the reference emulsion were overall small and inconclusive. In 2014, application of AR resulted in somewhat softer fruit in comparison with unsprayed trees whereas in 2015, fruit firmness instead increased significantly when the AR emulsion was applied in August or in June + August (Table 3). Spraying with the reference emulsion produced slightly softer fruit compared to AR. Neither AR nor reference emulsion had any effect on the soluble solids concentration (SSC) in 2014 whereas marginally higher SSC was noted in 2015 in comparison with unsprayed trees. Application of the AR and reference emulsion decreased the color index in 2014 but had no effect in 2015 when the control fruit had much lower values compared to the previous year (Table 3 ). 
TABLE 1. Fruit yield per tree and fruit weight in an apple orchard sprayed with AR or reference emulsions 2014 and 2015.

\begin{tabular}{|c|c|c|c|c|c|c|}
\hline \multirow{2}{*}{ Treatment } & \multirow{2}{*}{ Application time } & \multicolumn{2}{|c|}{ Yield $\left(\mathrm{kg}\right.$ tree $\left.{ }^{-1}\right)$} & \multicolumn{3}{|c|}{ Fruit weight (g) } \\
\hline & & 2014 & 2015 & 2014 & & 2015 \\
\hline \multirow{7}{*}{$\begin{array}{l}\text { AR emulsion } \\
0.025 \%\end{array}$} & June & $4.5 \pm 3.5 \mathrm{ef}^{z}$ & $2.7 \pm 1.3$ cdef & $198 \pm 98$ & $a b c$ & $115 \pm 20 a b c$ \\
\hline & July & - & $1.1 \pm 0.3 \mathrm{f}$ & - & & $91 \pm 13$ bcde \\
\hline & August & $6.2 \pm 2.1 \mathrm{cdef}$ & $4.0 \pm 2.0$ bcde & $95 \pm 19$ & e & $124 \pm 15 a$ \\
\hline & September & $4.9 \pm 1.2 \mathrm{def}$ & $4.8 \pm 0.9 b c$ & $100 \pm 6$ & e & $101 \pm 7$ abcde \\
\hline & June + Sep. & $5.1 \pm 1.2$ def & $3.9 \pm 1.5$ bcde & $214 \pm 20$ & $a b$ & $84 \pm 7$ de \\
\hline & June + Aug. & $4.7 \pm 1.2$ ef & $1.9 \pm 0.8$ ef & $181 \pm 10$ & $a b c$ & $84 \pm 9$ de \\
\hline & Aug. + Sep. & $11.3 \pm 0.5 \mathrm{a}$ & $4.1 \pm 0.8 \mathrm{bcd}$ & $157 \pm 10$ & bcde & $127 \pm 18 a$ \\
\hline \multirow{7}{*}{$\begin{array}{l}\text { Ref emulsion } \\
0.0 \%\end{array}$} & June & $3.6 \pm 0.3 f$ & $5.8 \pm 2.1 \quad b$ & $208 \pm 28$ & $a b c$ & $129 \pm 22 a$ \\
\hline & July & - & $2.9 \pm 0.1$ cdef & - & & $110 \pm 12$ abcde \\
\hline & August & $6.5 \pm 0.8 \mathrm{cde}$ & $2.0 \pm 0.5$ def & $177 \pm 10$ & $a b c d$ & $88 \pm 17$ cde \\
\hline & September & $5.5 \pm 0.7$ def & $5.6 \pm 0.4 \quad b$ & $113 \pm 11$ & de & $114 \pm 12 a b c$ \\
\hline & June + Sep. & $3.6 \pm 0.4 f$ & $3.2 \pm 0.7$ cdef & $224 \pm 16$ & a & $81 \pm 15$ e \\
\hline & June + Aug. & $8.8 \pm 1.1 \mathrm{abc}$ & $4.4 \pm 0.2 b c$ & $169 \pm 17$ & $a b c d$ & $113 \pm 13 \mathrm{abcd}$ \\
\hline & Aug. + Sep. & $9.8 \pm 1.3 \mathrm{ab}$ & $6.1 \pm 1.4 \quad b$ & $150 \pm 14$ & cde & $115 \pm 13 a b c$ \\
\hline Unsprayed trees & & $7.5 \pm 0.7 \mathrm{bcd}$ & $8.5 \pm 0.8 \quad a$ & $112 \pm 15$ & de & $122 \pm 19 a b$ \\
\hline$P$ & & 0.000 & 0.000 & 0.000 & & 0.000 \\
\hline
\end{tabular}

\pm SD. Data were evaluated using a one-way ANOVA with Tukey's HSD post-hoc test.

${ }^{z}$ Different letters indicate significant differences (Tukey's HSD $p<0.05$ ).

\section{Effects of orchard treatments on fruit storability}

Fungal decay during storage was significantly lower in fruit from trees sprayed with AR in comparison with fruit from unsprayed trees, whereas the reference emulsion had little effect (Table 4). Calculated across all treatments involving the application of AR compared to unsprayed trees, fungal decay was 50\% and 52\% lower after storage in regular air in 2014 and 2015, respectively, and 60\% and 70\% lower after storage in CA. When instead compared to trees treated with the reference emulsion, fungal decay in fruit from AR-treated trees decreased by $40 \%$ and $44 \%$ after storage in regular air in 2014 and 2015, respectively, and by $38 \%$ and $62 \%$ after storage in CA. Fruit from trees that were treated late in the season (August, September), once or twice, had significantly less decay (between 20 and 50\%) than fruit from trees treated early in June or July (Table 4).

Most of the fungal decay was caused by $N$. perennans, C. acutatum, $M$. fructigena or P. expansum. Percentage of damaged fruits from trees treated with either the reference or the
AR emulsion, is reported separately for fruit stored in regular air and in CA, respectively (Figure 1). In 2014, when lenticel rot caused by Neofabraea spp. was the most common storage disease, spraying trees with the AR emulsion decreased its occurrence by $23 \%$ (storage in air) and $57 \%$ (CA storage) in comparison with the reference emulsion. In 2015, when blue mold caused by Penicillium expansum instead was the most common disease, its occurrence was reduced by 52\% (air) and $57 \%$ (CA). In both years, bitter rot caused by C. acutatum came in second place. This fungus was reduced by $70 \%$ (air) and $80 \%$ (CA) in 2014, and by 50\% (air) and 65\% (CA) in 2015. Finally, brown rot caused by Monilinia fructigena was reduced by $75 \%$ (air) and $80 \%$ (CA) in 2014.

CA storage decreased the incidence of physiological disorders in comparison with storage in regular air, but there were no significant effects from spraying with the AR or reference emulsions. However, trees sprayed with AR earlier in the season showed a slightly higher frequency of soft scald on the fruit in comparison with trees that were sprayed later (data not shown).

TABLE 2. Number of fallen and infected (Monilinia fructigena) fruits under apple trees sprayed with AR or reference emulsions in 2015.

\begin{tabular}{lcc} 
Treatment & $\begin{array}{c}\text { Trees sprayed with AR emulsion } \\
(0.025 \%)\end{array}$ & $\begin{array}{c}\text { Trees sprayed with Ref emulsion } \\
(0.0 \%)\end{array}$ \\
\hline June & $1.70 \pm 0.51 \mathrm{efg} z$ & $5.40 \pm 0.84 \mathrm{ab}$ \\
July & $1.20 \pm 0.40 \mathrm{fg}$ & $2.50 \pm 0.45 \mathrm{def}$ \\
August & $1.90 \pm 0.41 \mathrm{efg}$ & $2.50 \pm 0.55 \mathrm{def}$ \\
September & $0.50 \pm 0.83 \mathrm{~g}$ & $2.00 \pm 0.63 \mathrm{ef}$ \\
June + August & $2.90 \pm 0.41 \mathrm{de}$ & $3.90 \pm 0.98 \mathrm{~cd}$ \\
June + September & $2.10 \pm 0.40 \mathrm{ef}$ & $4.70 \pm 0.75 \mathrm{abc}$ \\
August + September & $2.60 \pm 0.82 \mathrm{de}$ & $4.20 \pm 1.10 \mathrm{bc}$ \\
\hline Unsprayed trees & & \\
\hline$P$ & & \\
\hline
\end{tabular}

\pm SD, Data were evaluated using a one-way ANOVA with Tukey's HSD post-hoc test.

${ }^{z}$ Different letters indicate significant differences (Tukey's HSD $p<0.05$ ). 
TABLE 3. Firmness, SSC (soluble solids concentration) and color index for fruit harvested in an apple orchard sprayed with AR or reference emulsions 2014 and 2015. Upper half: data collected at harvest, Lower half: data collected after storage, only values for AR-sprayed trees reported.

\begin{tabular}{|c|c|c|c|c|c|c|c|c|}
\hline \multirow[b]{2}{*}{ Treatment } & \multirow[b]{2}{*}{ Application time } & \multicolumn{4}{|c|}{2014} & \multicolumn{3}{|c|}{2015} \\
\hline & & $\begin{array}{l}\text { Firmness } \\
\left(\mathrm{kg} \mathrm{cm}^{-2}\right)\end{array}$ & & & index & $\begin{array}{l}\text { Firmness } \\
\left(\mathrm{kg} \mathrm{cm}^{-2}\right)\end{array}$ & $\begin{array}{l}\text { SSC } \\
(\%)\end{array}$ & $\begin{array}{l}\text { Color } \\
\text { index }\end{array}$ \\
\hline \multirow{7}{*}{$\begin{array}{l}\text { AR emulsion } \\
0.025 \%\end{array}$} & June & $5.9 \mathrm{~cd}^{2}$ & \multicolumn{2}{|c|}{$12.6 \mathrm{a}$} & $15.4 \mathrm{~cd}$ & $8.3 a b$ & $13.3 \mathrm{abc}$ & $22.9 a$ \\
\hline & July & - & \multicolumn{2}{|c|}{-} & - & $8.2 \mathrm{abc}$ & $13.7 \mathrm{abc}$ & $28.5 \mathrm{a}$ \\
\hline & August & $6.9 \mathrm{ab}$ & \multicolumn{2}{|c|}{$12.3 \mathrm{a}$} & 17.8 bc & $8.8 \mathrm{a}$ & $13.5 \mathrm{abc}$ & $27.7 \mathrm{a}$ \\
\hline & September & $6.5 \mathrm{bc}$ & \multicolumn{2}{|c|}{$12.7 \mathrm{a}$} & $17.0 \mathrm{c}$ & $8.6 a b$ & $13.4 \mathrm{abc}$ & $26.8 \mathrm{a}$ \\
\hline & June + Sep. & $5.3 d$ & \multicolumn{2}{|c|}{$12.6 \mathrm{a}$} & $26.3 b$ & $8.2 \mathrm{abc}$ & $13.3 \mathrm{abc}$ & $23.0 \mathrm{a}$ \\
\hline & June + Aug. & $6.2 \mathrm{bc}$ & \multicolumn{2}{|c|}{$12.9 \mathrm{a}$} & $16.6 \mathrm{~cd}$ & $8.8 \mathrm{a}$ & $14.4 \mathrm{a}$ & $24.6 \mathrm{a}$ \\
\hline & Aug. + Sep. & $6.6 \mathrm{bc}$ & \multicolumn{2}{|c|}{$13.1 \mathrm{a}$} & $25.1 \mathrm{bc}$ & $7.9 \mathrm{bcd}$ & $13.3 \mathrm{abc}$ & $23.8 \mathrm{a}$ \\
\hline \multirow{7}{*}{$\begin{array}{l}\text { Ref emulsion } \\
(0.00 \%)\end{array}$} & June & $5.4 d$ & \multicolumn{2}{|c|}{$12.5 \mathrm{a}$} & $29.1 \mathrm{ab}$ & $8.1 \mathrm{abcd}$ & $12.6 \mathrm{bc}$ & $28.6 \mathrm{a}$ \\
\hline & July & - & & & - & $7.3 \mathrm{~cd}$ & $13.4 \mathrm{abc}$ & $21.6 \mathrm{a}$ \\
\hline & August & $5.9 \mathrm{~cd}$ & & & $25.6 \mathrm{bc}$ & $8.2 a b$ & $13.6 \mathrm{abc}$ & $30.2 \mathrm{a}$ \\
\hline & September & $5.7 d$ & & & $22.1 \mathrm{bc}$ & $7.8 \mathrm{bcd}$ & $13.0 \mathrm{abc}$ & $25.7 \mathrm{a}$ \\
\hline & June + Sep. & $5.6 \mathrm{~d}$ & & & $13.9 \mathrm{~d}$ & $8.1 \mathrm{abcd}$ & $14.0 \mathrm{ab}$ & $27.7 \mathrm{a}$ \\
\hline & June + Aug. & $5.4 \mathrm{~d}$ & & & $17.6 \mathrm{bcd}$ & $7.7 \mathrm{bcd}$ & $13.5 \mathrm{abc}$ & $25.4 \mathrm{a}$ \\
\hline & Aug. + Sep. & $5.3 d$ & & & $18.5 \mathrm{bcd}$ & $7.2 \mathrm{~d}$ & $13.3 \mathrm{abc}$ & $20.5 \mathrm{a}$ \\
\hline Unsprayed trees & & $7.5 \mathrm{a}$ & & & $38.1 \mathrm{a}$ & $7.8 \mathrm{bcd}$ & $12.4 \mathrm{C}$ & $25.7 \mathrm{a}$ \\
\hline Application time, & & 201 & & & & & 015 & \\
\hline AR emulsion & Regul & storage & & rage & & ular air storage & & age \\
\hline & Firm. & SSC & Firm. & SSC & & SSC & Firm. & SSC \\
\hline June & $4.1 b^{2}$ & $13.1 \mathrm{a}$ & $4.4 \mathrm{~d}$ & $14.4 \mathrm{bc}$ & & $15.5 \mathrm{a}$ & $4.9 \mathrm{ab}$ & $14.8 \mathrm{a}$ \\
\hline July & - & - & - & - & & $14.0 \mathrm{bc}$ & $5.5 \mathrm{a}$ & $14.8 \mathrm{a}$ \\
\hline August & $5.5 \mathrm{a}$ & $13.8 \mathrm{a}$ & $5.7 a b$ & $15.8 \mathrm{a}$ & & $14.7 \mathrm{ab}$ & $5.5 \mathrm{a}$ & $15.2 \mathrm{a}$ \\
\hline September & $5.3 a$ & $13.7 \mathrm{a}$ & $5.3 b c$ & $15.0 \mathrm{ab}$ & & $13.6 \mathrm{~cd}$ & $5.8 \mathrm{a}$ & $14.4 a b$ \\
\hline June + Aug. & $4.4 \mathrm{~b}$ & $14.0 \mathrm{a}$ & $4.6 \mathrm{~cd}$ & $14.3 \mathrm{bc}$ & & $12.8 b$ & $5.1 \mathrm{a}$ & $14.2 b$ \\
\hline June + Sep. & $5.3 \mathrm{a}$ & $13.3 \mathrm{a}$ & $5.8 a b$ & $15.6 \mathrm{a}$ & & $14.4 \mathrm{a}$ & $5.7 \mathrm{a}$ & $14.5 a b$ \\
\hline Aug. + Sep. & $5.8 \mathrm{a}$ & $14.2 \mathrm{a}$ & $6.1 \mathrm{a}$ & $15.1 \mathrm{ab}$ & & $14.9 \mathrm{a}$ & $5.2 \mathrm{a}$ & $14.9 \mathrm{a}$ \\
\hline Unsprayed trees & $4.0 \mathrm{~b}$ & $13.0 \mathrm{a}$ & $5.1 \mathrm{bc}$ & $14.0 \mathrm{C}$ & & $12.8 b$ & $5.0 \mathrm{a}$ & $13.8 \mathrm{a}$ \\
\hline
\end{tabular}

Data were evaluated using a one-way ANOVA with Tukey's HSD post-hoc test.

z Different letters indicate significant differences (Tukey's HSD $p<0.05$ ).

TABLE 4. Occurrence of fungal decay (\%) during storage of fruit harvested in an apple orchard sprayed with AR or reference emulsions 2014 and 2015 (total occurrence of various fungi).

\begin{tabular}{|c|c|c|c|c|c|}
\hline \multirow{2}{*}{ Treatment } & \multirow{2}{*}{ Application time } & \multicolumn{2}{|c|}{2014} & \multicolumn{2}{|c|}{2015} \\
\hline & & Regular air & $\mathrm{CA}$ & Regular air & $\mathrm{CA}$ \\
\hline \multirow{7}{*}{$\begin{array}{l}\text { AR emulsion } \\
0.025 \%\end{array}$} & June & $31.7 \pm 2.9 \mathrm{a}^{z}$ & $23.3 \pm 5.8 \mathrm{bcd}$ & $14.2 \pm 2.9 \mathrm{~cd}$ & $6.7 \pm 0.2 a b c$ \\
\hline & July & - & - & $11.7 \pm 1.4$ cde & $6.7 \pm 0.2 a b c$ \\
\hline & August & $15.0 \pm 3.9 \mathrm{~cd}$ & $13.5 \pm 0.2$ ef & $8.3 \pm 1.5 \mathrm{de}$ & $5.6 \pm 3.9 \mathrm{bc}$ \\
\hline & September & $14.4 \pm 1.9 \mathrm{~cd}$ & $12.8 \pm 2.1$ ef & $5.8 \pm 1.5 \mathrm{e}$ & $4.4 \pm 1.9 b c$ \\
\hline & June + Aug. & $13.5 \pm 3.3 d$ & $9.0 \pm 2.7 \mathrm{f}$ & $13.3 \pm 1.4 \mathrm{~cd}$ & $3.3 \pm 1.9 \mathrm{c}$ \\
\hline & June + Sep. & $17.5 \pm 4.2 \mathrm{bcd}$ & $15.0 \pm 1.0$ def & $11.7 \pm 3.8$ cde & $2.2 \pm 0.3 c$ \\
\hline & August + Sep. & $8.6 \pm 6.7 \mathrm{e}$ & $9.1 \pm 1.8 \mathrm{f}$ & $8.3 \pm 1.5 \mathrm{de}$ & $2.2 \pm 1.9 c$ \\
\hline \multirow{7}{*}{$\begin{array}{l}\text { Ref. emulsion } \\
0.0 \%\end{array}$} & June & $27.5 \pm 3.7 a b c$ & $15.2 \pm 1.7$ def & $15.8 \pm 3.8 b c$ & $13.3 \pm 3.3 \mathrm{ab}$ \\
\hline & July & - & - & $20.8 \pm 2.9 a b$ & $15.6 \pm 3.8 \mathrm{a}$ \\
\hline & August & $14.3 \pm 3.7 \mathrm{~cd}$ & $26.9 \pm 0.4 a b c$ & $21.7 \pm 1.5 a b$ & $10.0 \pm 3.3 a b c$ \\
\hline & September & $14.2 \pm 9.0 \mathrm{~cd}$ & $20.2 \pm 5.9$ cde & $14.2 \pm 1.4 \mathrm{~cd}$ & $8.9 \pm 1.9 a b c$ \\
\hline & June + Aug. & $33.6 \pm 1.7 \mathrm{a}$ & $30.1 \pm 3.2 a b$ & $20.8 \pm 1.6 a b$ & $9.1 \pm 0.8 \mathrm{abc}$ \\
\hline & June + Sep. & $34.4 \pm 5.5 \mathrm{a}$ & $21.3 \pm 1.6$ bcde & $20.8 \pm 1.6 a b$ & $13.3 \pm 6.7 \mathrm{ab}$ \\
\hline & August + Sep. & $29.6 \pm 6.2 \mathrm{ab}$ & $24.8 \pm 2.1 \mathrm{bc}$ & $17.5 \pm 2.5 \mathrm{bc}$ & $10.0 \pm 3.3 \mathrm{abc}$ \\
\hline Unsprayed trees & & $38.7 \pm 1.9 \mathrm{a}$ & $35.3 \pm 3.9 \mathrm{a}$ & $24.2 \pm 1.5 \mathrm{a}$ & $15.6 \pm 3.8 \mathrm{a}$ \\
\hline$P$ & & 0.000 & 0.000 & 0.000 & 0.000 \\
\hline
\end{tabular}

\pm SD, Data were evaluated using a one-way ANOVA with Tukey's HSD post-hoc test.

${ }^{z}$ Different letters indicate significant differences (Tukey's HSD $p<0.05$ ). 


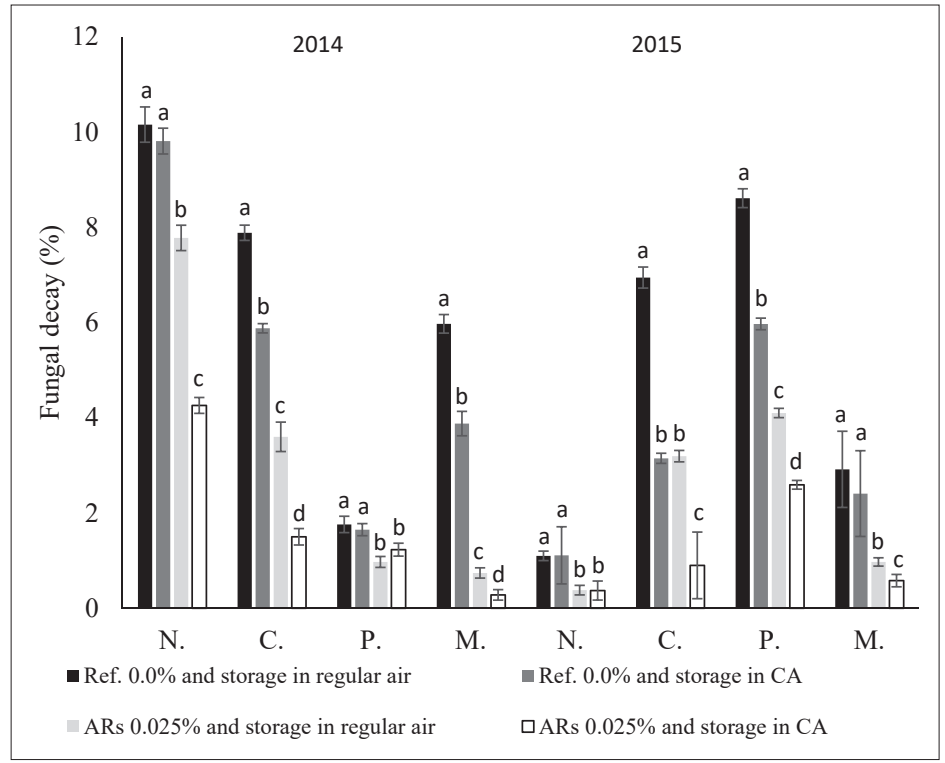

FiguRE 1. Decay caused by different fungi in fruit harvested from trees sprayed with a reference emulsion and an AR emulsion, respectively, and stored in regular air or CA. N. Neofabraea spp., C. Colletotrichum spp., P. Penicillium expansum and M. Monilinia fructigena. Bars mean \pm SD. Data were evaluated using a one-way ANOVA with Tukey's HSD post-hoc test. ${ }^{2}$ Different letters indicate significant differences between treatments among each fungi (Tukey's HSD, $\mathrm{p}<0.05$ ).

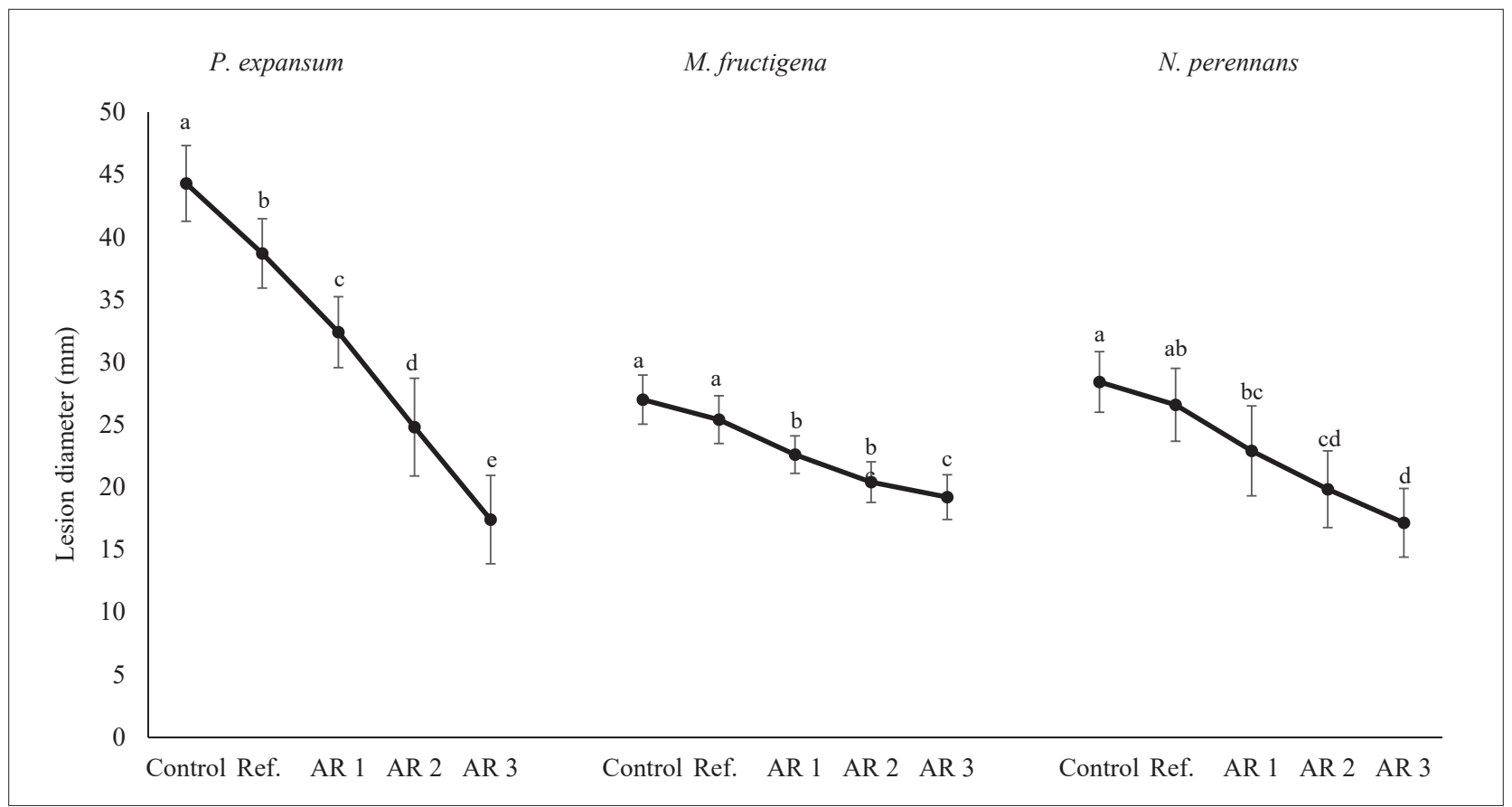

FIGURE 2. Effect of postharvest treatment with different concentrations of AR (Ref. 0.0\%, AR1 0.025\%, AR2 0.1\%, AR3 0.2\%) on diameter of lesions caused by inoculation with three fungi (2015). Bars mean \pm SD. Data were evaluated using a one-way ANOVA with Tukey's HSD post-hoc test. ${ }^{2}$ Different letters indicate significant differences between treatments among each fungi (Tukey's HSD, p<0.05).

Scoring the fruit after storage showed that application of the AR or reference emulsion had no effect on fruit color (data not shown). By contrast, firmness after storage was somewhat higher in fruit from the majority of the spraying treatments compared with fruit from unsprayed trees (Table 3). Spraying trees with the AR emulsion later in the season (August, September) was apparently more beneficial for retaining fruit firmness than spraying trees earlier in the season (June). Fruit from AR-treated trees also had higher SSC after storage than fruit from unsprayed trees. Frequency and time of spraying did not affect this relationship.

\section{Postharvest applications of ARs on inoculated fruits (in vivo)}

Spraying fruits with Ref, AR1, AR2 and AR3 $(0.00 \%$, $0.025 \%, 0.10 \%$ and $0.20 \%$ ARs) decreased the diameter of lesions caused by inoculation with P. expansum by $12 \%, 27 \%$, $44 \%$ and $61 \%$, respectively, in comparison with lesions on inoculated but unsprayed control fruit (Figure 2). A very strong negative correlation was found between AR concentration in the emulsion and lesion area diameter $(\mathrm{r}=-0.83, P<0.001)$. Corresponding values after inoculation with $N$. perennans were $0 \%, 19 \%, 30 \%$ and $40 \%$, respectively, and a significant 


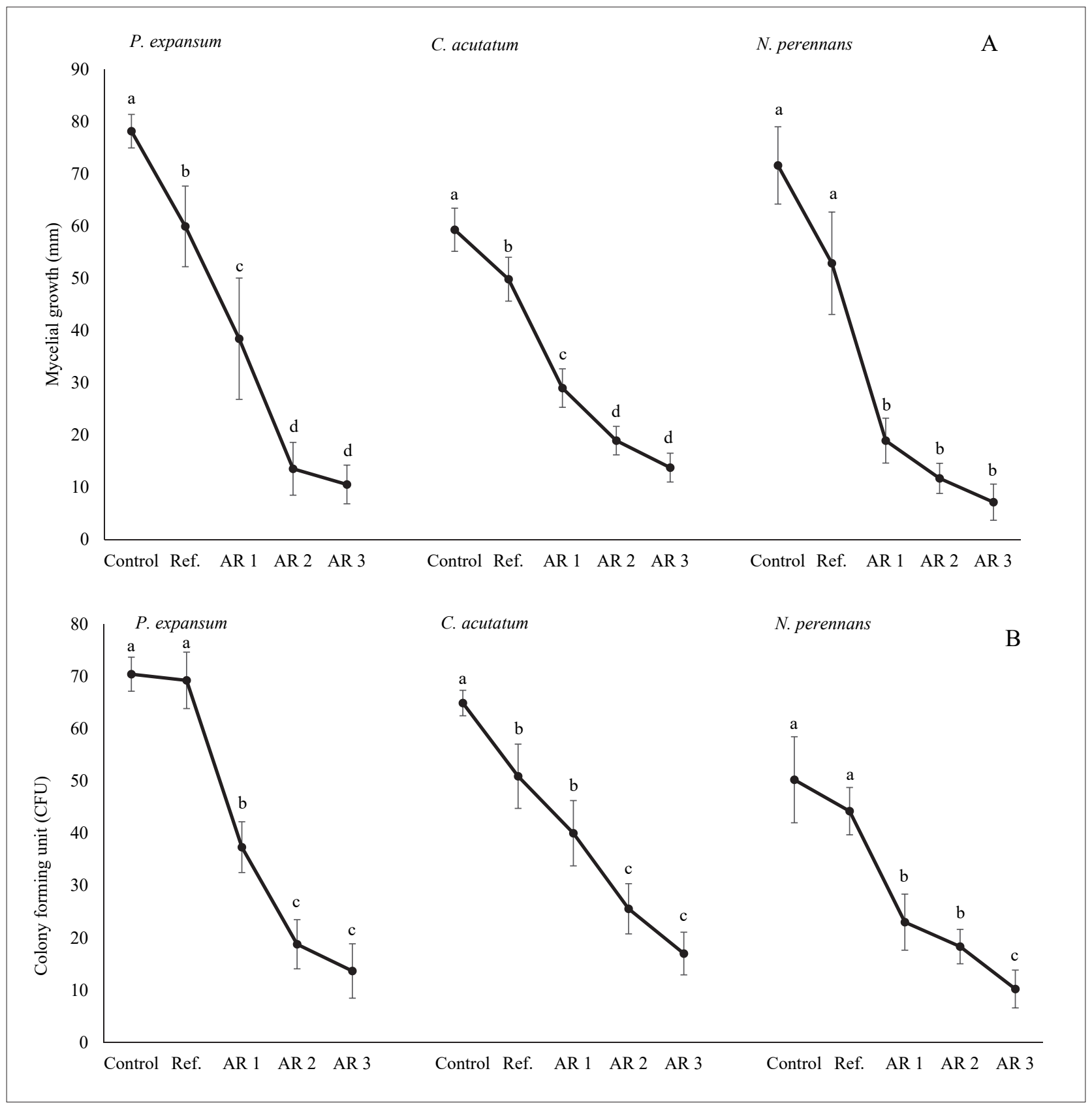

FIGURE 3. Antifungal effects of different concentrations of AR (Ref. $0.0 \%$, AR1 $0.025 \%$, AR2 $0.1 \%$, AR3 $0.2 \%$ ) on in vitro growth of three fungi (2015). Bars mean \pm SD. Data were evaluated using a one-way ANOVA with Tukey's HSD post-hoc test. ${ }^{2}$ Different letters indicate significant differences between treatments among each fungi (Tukey's HSD, $p<0.05$ ). A: inhibition of mycelial growth; B: inhibition of conidia viability.

negative correlation $(\mathrm{r}=-0.57, P<0.001)$. For fruit inoculated with $M$. fructigena the AR-induced reduction was $0 \%, 16 \%$, $24 \%$ and $29 \%$, and again a significant negative correlation $(\mathrm{r}=-0.58, P<0.001)$.

\section{Effects of AR on mycelial growth and conidia viability (in vitro)}

In vitro assays showed a significant antifungal activity of the different AR emulsions. Mycelial growth of $P$. expansum decreased by $23 \%, 51 \%, 83 \%$ and $86 \%$, respectively, after treatment with Ref, AR1, AR2 and AR3, in comparison with untreated plates (Figure 3A). A similar effect was observed for the mycelial growth of $C$. acutatum, which decreased by $15 \%$,
$51 \%, 67 \%$ and $77 \%$, and for $N$. perennans, which decreased by $12 \%, 74 \%, 83 \%$ and $90 \%$. Negative correlations were found between AR concentration and mycelial growth of $P$. expansum ( $\mathrm{r}=-0.60, P=0.001)$, of $C$. acutatum $(\mathrm{r}=-0.72, P<0.001)$ and of $N$. perennans $(\mathrm{r}=0.45, P=0.002)$.

Viability of $P$. expansum conidia treated with Ref, AR1, AR2 or AR3 was inhibited by $0 \%, 46 \%, 72 \%$ and $79 \%$, respectively, in comparison with the control (Figure 3B). There was no significant difference between the two emulsions with the highest AR concentration. For conidia of $C$. acutatum the viability decreased by $21 \%, 38 \%, 60 \%$ and $74 \%$, respectively, and AR2 and AR3 again produced similar inhibitory effects. Conidia of $N$. perennans showed $12 \%, 54 \%, 64 \%$ and $80 \%$ decreased via- 
bility, with a significantly higher effect of AR3 in comparison with the other emulsions. Significant, negative correlations were found between AR concentrations and conidia viability of the three pathogens, strong in the case of $P$. expansum ( $\mathrm{r}=$ $-070, P<0.001)$ and $C$. acutatum $(\mathrm{r}=-0.72, P<0.001)$ and somewhat weaker in the case of $N$. perennans ( $\mathrm{r}=-0.49, P=0.008$ ). However, the lowest concentration (AR1) always showed the smallest inhibitory effect among the AR treatments.

\section{Discussion}

Use of chemical fungicides in conventional apple orchards is being increasingly restricted in many countries due to environmental concerns. Simultaneously, consumer interest in organically grown products increases, partly brought about also by human health concerns. Development of adequate plant protection remedies for use in organic fruit orchards is, however, insufficient and no effective methods for control of storage diseases are presently approved. A number of natural substances have shown good potential in initial trials, but most of them have never been developed into commercial products (Plotto et al., 2006). Among these undeveloped but promising substances are the alkylresorcinols, which occur naturally in some plants and reduce damage caused by, e.g., the rice blast fungus Pyricularia oryzae in rice (Suzuki et al., 1996) and by Colletotrichum gloeosporioides in mango (Hassan et al., 2007).

Two hydroxyl groups at positions C1 and C3 of the aromatic ring, and a lipophilic alkyl chain at the $\mathrm{C} 5$ position characterize the 5-n-alkylresorcinols. The amphiphilic properties could be responsible for the ability of ARs to interact with biological membranes, nucleic acids and enzymes and to have a strong antimicrobial effect (Stasiuk and Kozubek, 2008). AR emulsions are able to inhibit the activity of several enzymes such as DNA repair enzyme, DNA polymerase B (Stasiuk and Kozubek, 2010) and $\mathrm{NADH}^{+}$-dependent enzymes associated with respiration and photosynthesis (Nenashev et al., 1989). In addition, the anti-oxidative effect of the AR molecules probably contribute to the inhibition of fungal growth and spore shrinkage and deformation (Zainuri et al., 2013).

\section{Effects of ARs on storage diseases in apple}

In apple, the antifungal effects of 19 different emulsions containing rye bran-derived ARs, have been examined on harvested fruit inoculated with P. expansum (Dey et al., 2013). Most of these emulsions reduced lesion area in comparison with the control fruit. In another study, two AR emulsions showed a strong inhibitory effect on lesion development in fruit inoculated with $P$. expansum and $N$. perennans as well as on mycelial growth and spore germination of these two pathogens (Tahir et al., 2014).

In the present study conducted in an organic 'Aroma' orchard, the amount of Monilinia fructigena-infected fruit that fell to the ground in August and September, was approximately halved when the trees had been sprayed with AR emulsion. The resulting reduction in source of inoculum would be very valuable for limiting fungal invasion by dispersal of conidia from the fallen fruit (Børve and Stensvand, 2007; Holb and Scherm, 2007). When fruit was evaluated after storage in regular air or CA, similar effects of AR sprayings were observed; decay was approximately halved for the four screened pathogens. Late-season (August and/or September) applications were more efficient suggesting that the last weeks before harvest constitute the most critical period of spore dispersal in the field, as previously reported (Chaves et al., 2014; Aguilar et al., 2017).
No negative effects from application of ARs were found on fruit quality (color, firmness, SSC) in the present study. Especially in 2015, AR treatment instead appears to have increased fruit firmness slightly, both at harvest and after storage. This may, in turn, have contributed to protection from fungal infestations since fruit firmness both at harvest and after storage is significantly correlated with the ability to withstand fungal attacks (Ahmadi-Afzadi et al., 2013).

Our results provide evidence that AR has the potential to become a natural, safe and eco-friendly remedy for control of fungal storage diseases. One negative side effect from using ARs was, however, the yield reduction encountered especially after early-season applications (June, July). Most of this yield reduction was obtained also when using the reference emulsion. One or more of the substances in the spraying emulsion may be responsible for this problem. Therefore, further studies on these substances are needed.

\section{Optimization of the AR concentration}

High contents of ARs occur in, e.g., the under-utilized waste product rye bran. Nevertheless, the isolation procedure is expensive and AR concentration should be optimized to produce a cost-effective and efficient emulsion without any undesirable side effects. A concentration of $10 \mathrm{mg} \mathrm{mL}^{-1}$ (1\%) of rye-derived ARs in a malt extract agar medium was needed to repress in vitro growth of Aspergillus parasiticus whereas three other bread moulds were unaffected at this concentration (Reiss, 1989). By contrast, mycelial growth was totally inhibited by adding rye-derived ARs to the agar media at a concentration as low as $260 \mu \mathrm{g} \mathrm{m}^{-1}(0.026 \%)$ for Fusarium culmorum and at 70-80 $\mu \mathrm{g} \mathrm{mL}-1$ (0.007-0.008\%) for Rhizoctonia cerealis and R. solani (Zarnowski et al., 1999).

Our in vitro experiment with three pathogens (P. expansum, $C$. acutatum and $N$. perennans) decreased mycelial growth as well as conidia viability when emulsions with $0.025 \%, 0.1 \%$ and $0.2 \%$ ARs were sprayed onto the plates. Effects of the two higher concentrations were similar but in most cases improved the antifungal activity significantly when compared to $0.025 \%$. Impact of AR concentration was also investigated in fruit that had been inoculated with three pathogens (in vivo). Concentration showed a very clear effect in the case of $P$. expansum, but the highest concentration was significantly more efficient than the lowest also for $N$. perennans and M. fructigena.

\section{Conclusions}

Spraying apple trees with an AR emulsion decreases fungal attacks significantly, both on fruit at harvest (mainly Monilinia fructigena) and after storage (mainly N. perennans, P. expansum, C. acutatum and M. fructigena). Effects on fruit quality, assessed as firmness, color and soluble solids concentration, are small and inconsistent. Yield is, however, reduced but this is probably connected to the solvents (i.e., salts) since a similar yield reduction was obtained after application of a reference emulsion without ARs.

Application of emulsions with $0.025 \%, 0.1 \%$ or $0.2 \%$ ARs on harvested and inoculated fruit (in vivo) and on fungal mycelia and conidia (in vitro) shows that the anti-fungal effect increases linearly with AR concentration. Only the lowest concentration $(0.025 \%)$ was used in the orchard trial, but an emulsion with $0.1-0.2 \%$ could probably be cost-effective if the improvement of anti-fungal effects from spraying trees are similar to the improvement of anti-fungal effects on inoculated fruits in the in vivo trial. 


\section{Acknowledgments}

This study was supported by a grant to Hilde Nybom from SLU EkoForsk. The authors are grateful to Kiviks musteri for technical support in the orchard trial.

\section{References}

Aguilar, C.G., Mazzola, M., and Xiao, C.L. (2017). Timing of apple fruit infection by Neofabraea perennans and Neofabraea kienholzii in relation to bull's-eye rot development in stored apple fruit. Plant Dis. 101, 800-806. https://doi.org/10.1094/PDIS-11-16-1637-RE.

Ahmadi-Afzadi, M., Tahir, I., and Nybom, H. (2013). Impact of harvesting time and fruit firmness on the tolerance to fungal storage diseases in an apple germplasm collection. Postharv. Biol. Technol. 82, 51-58. https://doi.org/10.1016/j.postharvbio.2013.03.001.

Ahuja, I., Kissen, R., and Bones, A.M. (2012). Phytoalexins in defense against pathogens. Trends Pl. Sci. 17, 73-90. https://doi. org/10.1016/j.tplants.2011.11.002.

Arif, T., Bhosalea, J.D., Kumara, N., Mandala, T.K., Bendreb, R.S., Lavekara, G.S., and Dabura, R. (2009). Natural products - antifungal agents derived from plants. J. Asian Nat. Prod. Res. 11, 621-638. https://doi.org/10.1080/10286020902942350.

Baerson, S.R., Schroder, J., Cook, D., Rimando, A.M., Pan, Z., Dayan, F.E., Noonan, B.P., and Duke, S.O. (2010). Alkylresorcinol biosynthesis in plants: new insights from an ancient enzyme family. Plant Signal Behav. 5, 1-4. https://doi.org/10.4161/psb.5.10.13062.

Børve, J., and Stensvand, A. (2007). Colletotrichum acutatum found on apple buds in Norway. Plant Health Progress. doi: 10.1094/PHP0522-01-RS.

Chávez, R.A.S., Peniche, R.T.M., Medrano, S.A., Muñoz, L.S., Ortíz, M.D.S.C., Espasa, N.T., and Sanchis, R.T. (2014). Effect of maturity stage, ripening time, harvest year and fruit characteristics on the susceptibility to Penicillium expansum Link. of apple genotypes from Queretaro, Mexico. Sci. Hortic. 180, 86-93. https://doi. org/10.1016/j.scienta.2014.10.014.

Cojocaru, M., Droby, S., Glotter, E., Goldman, A., Gottlieb, H.E., Jacoby, B., and Prusky, D. (1986). 5-(12-Heptadecenyl)-resorcinol, the major component of the antifungal activity in the peel of mango fruit. Phytochemistry 25, 1093-1095. https://doi.org/10.1016/S00319422(00)81560-5.

Dai, J., and Mumper, R.S. (2010). Plant phenolics: extraction, analysis and their antioxidant and anticancer properties. Molecules 15, 7313-7352. https://doi.org/10.3390/molecules15107313.

Dey, S.E., and Mikhailopulo, K. (2009). A food grade approach for the isolation of major alkylresorcinols from rye bran applying tailored supercritical carbon dioxide $\left(\mathrm{scCO}_{2}\right)$ extraction combined with HPLC. J. Supercrit. Fluids 51, 167-173. https://doi.org/10.1016/j. supflu.2009.09.005.

Dey, S.E., Ahmadi-Afzadi, M., Nybom, H., and Tahir, I. (2013). Alkylresorcinols isolated from rye bran by supercritical fluid of carbon dioxide and suspended in a food-grade emulsion show activity against Penicillium expansum on apples. Arch. Phytopathol. Plant Protect. 46, 105-119. https://doi.org/10.1080/03235408.20 12.734719.

Di Francesco, A., Martini, C., and Mari, M. (2016). Biological control of post-harvest diseases by microbial antagonists: how many mechanisms of action? Eur. J. Plant Path. 145(4), 711-717. https:// doi.org/10.1007/s10658-016-0867-0.

Feliziani, E., Smilanick, J.L., Margosan, D.A., Mansour, M.F., Romanazzi, G., Gu, S., Gohil, H.L., and Rubio Ames, Z. (2013). Preharvest fungicide, potassium sorbate, or chitosan use on quality and storage decay of table grapes. Plant Dis. 97, 307-314. https://doi.org/10.1094/PDIS12-11-1043-RE.
Gajda, A., Kulawinek, M., and Kozubek, A. (2008). An improved colorimetric method for the determination of alkylresorcinols in cereals and whole-grain cereal products. J. Food Comp. Anal. 21, 428-434. https://doi.org/10.1016/j.jfca.2008.04.002.

Garcìa, S., Garcìa, C., Heinzen, H., and Moyna, P. (1997). Chemical basis of the resistance of barley seeds to pathogenic fungi. Phytochemistry 44, 415-418. https://doi.org/10.1016/S0031-9422(96)00511-0.

Hassan, M.K., Dann, E.K., Irving, D.E., and Coates, L.M. (2007). Concentrations of constitutive alk(en)ylresorcinol in peel of commercial mango varieties and resistance to postharvest anthracnose. Physiol. Mol. Plant Pathol. 71, 158-165. https://doi. org/10.1016/j.pmpp.2007.12.005.

Holb, I.J., and Scherm, H. (2007). Temporal dynamics of brown rot in different apple management systems and importance of dropped fruit for disease development. Phytopathology 97, 1104-1111. https://doi.org/10.1094/PHYTO-97-9-1104.

Jing, L., Lei, Z., Li, L., Xie, R., Xi, W., Guan, Y., and Zhou, Z. (2014). Antifungal activity of citrus essential oils. J. Agric. Food Chem. 62, 3011-3033. https://doi.org/10.1021/jf5006148.

Jönsson, Å. (2007). Organic apple production in Sweden. Diss. (Swedish University of Agricultural Sciences), ISBN 1652-6880, No. 14.

Kozubek, A., Zarnowski, R., Stasiuk, M., and Gubernator, J. (2001). Natural amphiphilic phenols as bioactive compounds. Cellul. Molecul. Biol. Letters 6(2A), 351-355.

Morales, H., Marín, S., Ramos, A.J., and Sanchis, V. (2010). Influence of post-harvest technologies during cold storage of apples in Penicillium expansum growth and patulin accumulation: A review. Food Control 21, 953-962. https://doi.org/10.1016/j.foodcont.2009.12.016.

Nenashev, V.A., Pridachina, N.N., Pronevich, L.A., and Batrakov, S.G. (1989). 5-Alkyl (C19-25) resorcinols as regulators of the oxidation of succinate and NAD-dependent substrates by mitochondria. Biokhimiia 54, 784-787.

Nunes, C.,Usall,J., Teixido, N.,Abadias, I., Asensio, A., andVinas, I.(2007). Biocontrol of postharvest decay using a new strain of Pseudomonas syringae CPA-5 in different cultivars of pome fruit. Agric. Food Sci. 16, 56-65. https://doi.org/10.2137/145960607781635877.

Pérez-Alfonso, C.O., Martínez-Romero, D., Zapata, P.J., Serrano, M., Valero, D., and Castillo, S. (2012). The effects of essential oils carvacrol and thymol on growth of Penicillium digitatum and P. italicum involved in lemon decay. Int. J. Food Microbiol. 158, 101106. https://doi.org/10.1016/j.ijfoodmicro.2012.07.002.

Plotto, A., Bai, J., Narciso, J.A., Brecht, J.K., and Baldwin, E.A. (2006). Ethanol vapor prior to processing extends fresh-cut mango storage by decreasing spoilage, but does not always delay ripening. Postharv. Biol. Technol. 39, 134-145. https://doi.org/10.1016/j. postharvbio.2005.09.009.

Reiss, J. (1989). Influence of alkylresorcinols from rye and related compounds on the growth of food-borne moulds. Cereal Chem. 66, 491-493.

Ribeiro, S.M.R., Barbose, L.C.A., Queiroz, J.H., Knodler, M., and Schieber, A. (2008). Phenolic compounds and antioxidant capacity of Brazilian mango (Mangifera indica L.) varieties. Food Chem. 110, 620-626. https://doi.org/10.1016/j.foodchem.2008.02.067.

Romanazzi, G., Feliziani, E., Banos, S., and Sivakumar, D. (2017). Shelf life extension of fresh fruit and vegetables by chitosan treatment. Crit. Rev. Food Sci. Nutr. 57(3), 579-601. https://doi.org/10.1080/ 10408398.2014.900474.

Ross, A.B., Kamal-Eldin, A., and Åman, P. (2004). Dietary alkylresorcinols: absorption, bioactivities, and possible use as biomarkers of whole-grain wheat- and rye-rich foods. Nutr. 
Rev. 62(3), 81-95. https://doi.org/10.1111/j.1753-4887.2004. tb00029.x.

Saftner, R.A., Abbott, J.A., Conway, W.S., and Barden, C.L. (2003). Effects of 1-methylcyclopropene and heat treatments on ripening and postharvest decay in 'Golden Delicious' apples. J. Am. Soc. Hort. Sci. 128, 120-127. https://doi.org/10.21273/JASHS.128.1.0120.

Sholberg, P., Haag, P., Hocking, R., and Bedford, K. (2000). The use of vinegar vapor to reduce postharvest decay of harvested fruit. HortScience 35, 898-903. https://doi.org/10.21273/ HORTSCI.35.5.898.

Stasiuk, M., and Kozubek, A. (2008). Membrane perturbing properties of natural phenolic and resorcinolic lipids. FEBS Lett. 582, 3607-3613. https://doi.org/10.1016/j.febslet.2008.09.039.

Stasiuk, M., and Kozubek, A. (2010). Biological activity of phenolic lipids. Cell. Mol. Life Sci. 67, 841-860. https://doi.org/10.1007/ s00018-009-0193-1.

Streif, J. (1996). Optimum harvest date for different apple cultivars in the 'Bodensee' area. In The Postharvest Treatment of Fruit and Vegetables: Determination and Prediction of Optimum Harvest Date of Apple and Pears, A. De Jager, D. Johnson, and E. Hohn, eds. (Brussels, Belgium: COST 94), p. 15-20.

Suzuki, Y., Esumi, Y., Hyakutake, H., Kono, Y., and Sakurai, A. (1996). Isolation of 5-(8'Z-heptadecenyl)-resorcinol from etiolated rice seedlings as an antifungal agent. Phytochemistry 41, 1485-1489. https://doi.org/10.1016/0031-9422(95)00809-8.

Tahir, I., and Nybom, H. (2013). Tailoring organic apples by cultivar selection, production system, and post-harvest treatment to improve quality and storage life. Hortscience 48, 92-101. https://doi. org/10.21273/HORTSCI.48.1.92.

Tahir, I., Johansson, E., and Olsson, M.E. (2009). Improvement of apple quality and storability by a combination of heat treatment and controlled atmosphere storage. HortScience 44, 1648-1654. https://doi.org/10.21273/HORTSCI.44.6.1648.

Tahir, I., Ahmadi-Afzadi, M., Nybom, H., and Dey, E.Sz. (2014). Alkylresorcinols isolated from rye bran inhibit growth of Penicillium expansum and Neofabraea perennans in vitro and on fungalinoculated fruits of four apple cultivars. Eur. J. Hortic. Sci. 79, 218225 .

Yu, T., Chen, J.S., Lu, H.P., and Zheng, X.D. (2009). Indole-3-acetic acid improves postharvest biological control of blue mold rot of apple by Cryptococcus laurentii. Phytopathol. 99, 258-264. https://doi. org/10.1094/PHYTO-99-3-0258.

Zainuri, D.E., Irving, E.K., Dann, L.M., Coates, A., and Wearing, H. (2013). Alk(en)ylresorcinol concentrations in 'Kensington Pride' mango peel and antifungal activity against Colletotrichum gloeosporioides. Acta Hortic. 975, 217-222. https://doi org/10.17660/ActaHortic.2013.975.23.

Zarnowski, R., Kozubek, A., and Pietr, S.J. (1999). Effect of rye 5-n-alkylresorcinols on in vitro growth of phytopathogenic Fusarium and Rhizoctonia fungi. Bull. Polish Acad. Sci. Biol. Sci. 47, 231-235.
Received: Sep. 17, 2017

Accepted: Apr. 18, 2018

Addresses of authors:

Ibrahim Tahir ${ }^{1}$, Estera Szwajcer Dey ${ }^{2}$ and Hilde Nybom ${ }^{3, *}$

${ }^{1}$ Department of Plant Breeding, Swedish University of Agricultural Sciences, Box 101, SE-23053 Alnarp, Sweden

2 Division of Pure and Applied Biochemistry, Lund University, Box 124, SE-22100 Lund, Sweden

${ }^{3}$ Department of Plant Breeding-Balsgård, Swedish University of Agricultural Sciences, Fjälkestadsvägen 459, SE29194 Kristianstad, Sweden

* Corresponding author; E-mail: hilde.nybom@slu.se Tel.: +4644265802, +46703444369 